\title{
Optimized culture of retinal ganglion cells and amacrine cells from adult mice
}

\author{
Yong H. Park ${ }^{1}$, Joshua D. Snook ${ }^{1}$, Iris Zhuang ${ }^{1}$, Guofu Shen ${ }^{1}$, Benjamin \\ J. Frankfort $\mathbb{D}^{1,2 *}$ \\ 1 Department of Ophthalmology, Baylor College of Medicine, Houston, Texas, United States of America, \\ 2 Department of Neuroscience, Baylor College of Medicine, Houston, Texas, United States of America \\ * benjamin.frankfort@ bcm.edu
}

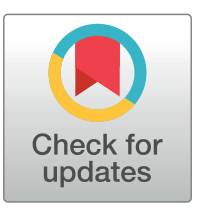

\section{G OPEn ACCESS}

Citation: Park YH, Snook JD, Zhuang I, Shen G, Frankfort BJ (2020) Optimized culture of retinal ganglion cells and amacrine cells from adult mice. PLOS ONE 15(12): e0242426. https://doi.org/ 10.1371/journal.pone.0242426

Editor: Rafael Linden, Universidade Federal do Rio de Janeiro, BRAZIL

Received: June 21, 2020

Accepted: November 2, 2020

Published: December 7, 2020

Copyright: $\odot 2020$ Park et al. This is an open access article distributed under the terms of the Creative Commons Attribution License, which permits unrestricted use, distribution, and reproduction in any medium, provided the original author and source are credited.

Data Availability Statement: All relevant data are within the manuscript.

Funding: This project was funded by research awards from the Clayton Foundation for Research (Houston, TX) and the National Institutes of Health (R01 EY025601) to BJF, and a department award to Baylor College of Medicine from Research to Prevent Blindness (New York, NY). The funders had no role in study design, data collection and analysis, decision to publish, or preparation of the manuscript.

\section{Abstract}

Cell culture is widely utilized to study the cellular and molecular biology of different neuronal cell populations. Current techniques to study enriched neurons in vitro are primarily limited to embryonic/neonatal animals and induced pluripotent stem cells (iPSCs). Although the use of these cultures is valuable, the accessibility of purified primary adult neuronal cultures would allow for improved assessment of certain neurological diseases and pathways at the cellular level. Using a modified 7-step immunopanning technique to isolate for retinal ganglion cells (RGCs) and amacrine cells (ACs) from adult mouse retinas, we have successfully developed a model of neuronal culture that maintains for at least one week. Isolations of Thy $1.2^{+}$cells are enriched for RGCs, with the isolation cell yield being congruent to the theoretical yield of RGCs in a mouse retina. ACs of two different populations (CD15 ${ }^{+}$and $\mathrm{CD}^{2} 7^{+}$) can also be isolated. The populations of these three adult neurons in culture are healthy, with neurite outgrowths in some cases greater than $500 \mu \mathrm{m}$ in length. Optimization of culture conditions for RGCs and $\mathrm{CD} 15^{+}$cells revealed that neuronal survival and the likelihood of neurite outgrowth respond inversely to different culture media. Serially diluted concentrations of puromycin decreased cultured adult RGCs in a dose-dependent manner, demonstrating the potential usefulness of these adult neuronal cultures in screening assays. This novel culture system can be used to model in vivo neuronal behaviors. Studies can now be expanded in conjunction with other methodologies to study the neurobiology of function, aging, and diseases.

\section{Introduction}

In vitro culture of enriched neuronal populations allows for enhanced study of direct/intrinsic factors under a variety of conditions. Such cultures are commonly derived from either embryonic/neonatal tissues [1-5] or induced pluripotent stem cells (iPSCs) [6-8]. Embryonic/neonatal tissues have weak neuronal connections which allow for their isolation and culture without severe injury [9] and are particularly useful for the study of neuronal development [10-13]. iPSCs can be used to generate many neurons, which makes them an ideal choice for high throughput experiments [14]. However, recent transcriptomic data show that iPSCs are 
Competing interests: The authors have declared that no competing interests exist. more similar to immature than mature neurons [15]. The immaturity of embryonic/neonatal and iPSC derived neurons therefore make them suboptimal for the study of age-related or inducible disorders.

As an extension of the CNS, the retina is a commonly used model to study different neuron types [16]. The retina is composed of several neuron types that are well characterized from early development through adult stages [17-27]. Within the retina, the RGCs primarily relay visual information to the brain [28]. In mice, RGCs are one of the least abundant retinal cell types, comprising only about $\sim 50,000$ cells [29]. This paucity of RGCs makes it challenging to study cell-specific changes to RGCs in development and disease. The challenges are even greater for in vitro assessments, and only a few studies have successfully cultured primary adult RGCs [30-35]. In these studies, adult RGC neurons were typically isolated at low cell yield, cultured for only a few days in vitro (DIV), and displayed little or no neurite outgrowth.

In this manuscript, we developed a 7-step immunopanning technique to isolate retinal neurons from adult mice. We successfully enriched three neuronal cell populations-RGCs and two subpopulations of ACs-and RGC yield was near the theoretical yield per retina. After one-week of culture (7 DIV), most cells remained viable. Surprisingly, many neurons also extended long neurites. Cell viability and neurite outgrowth were inversely affected by culture media conditions. Finally, RGCs treated with puromycin for 1 week showed a typical doseresponse curve, suggesting that these enriched adult neuronal cultures could be used for future screens.

\section{Materials and methods}

\section{Isolation and culture of adult mouse RGCs and ACs}

All procedures were performed under the Association for Research in Vision and Ophthalmology (ARVO) policy for animals in vision research and approved by the Institutional Animal Care and Use Committee (IACUC) of Baylor College of Medicine. Adult C57BL/6J mice of both genders were purchased from Jackson Labs (\#000664; Bar Harbor, ME). 12 week old mice were used for all primary studies. In some cases, additional RGCs were cultured from aged (>10 months) animals. Animals were euthanized by lethal overdose with a combination of ketamine and xylazine followed by decapitation to verify death. Retinas were promptly removed and RGCs and ACs purified utilizing a 7-step immunopanning technique modified from Barres et al. 1988 [2] and Park et al 2019 [36]. Dissected retinas were enzymatically digested with 9 units/mL of papain (\#LS003126; Worthington, Lakewood, NJ) for 30 mins at $34^{\circ} \mathrm{C}$ followed by trituration. Dissociated retinal cells were then sieved through a $20 \mu \mathrm{m}$ nylon mesh (\#SCNY00020; EMDMillipore, Burlington, MA) to remove tissue clumps, resulting in a retinal cell suspension. Cell suspensions were transferred and incubated onto two subsequent negative panning plates coated with unconjugated Griffonia (Bandeiraea) Simplicifolia Lectin 1 (BSL-1) (\#L-1100; Vector Laboratories, Burlingame, CA) as previously described [37], to remove monocytes and macrophages. A third negative plate coated with CD11b/c (\#554859; BD Pharmingen, San Jose, CA), also removed macrophages. Cone and rod photoreceptors were eliminated with two subsequent negative selection plates coated with peanut agglutinin (PNA) (\#L-1070; Vector Laboratories, Burlingame, CA) and monoclonal rat anti-mouse CD73 (clone TY/23) (\#550738; BD Pharmingen, San Jose, CA), respectively. The transfer of the retinal suspension onto panning plates bound with monoclonal mouse anti-SSEA-1 (CD15) (MC480 clone) (\#BD560079; BD Pharmingen, San Jose, CA) and monoclonal mouse antiHNK-1/N-CAM (CD57)(VC1.1 clone) (\#C6680-100TST; Sigma Aldrich, St. Louis, MO) allowed for the positive selections of ACs. Final panning using antibodies against Thy1.2 (CD90.2) (\#MCA02R; Bio-Rad Antibodies, Hercules, CA) positively selected for RGCs. 
Positive panning plates of $\mathrm{CD} 15^{+}, \mathrm{CD} 7^{+}$, and Thy $1.2^{+}$attached cells were washed with Dulbecco's Phosphate-Buffered Saline (DPBS) (\#14287072; Life Technologies, Carlsbad, CA), 15, 20 , and 25 times respectively, to eliminate non-adherent retinal cells. Adherent RGCs and ACs were treated with trypsin (1,250 units/mL) (\#T9935; Sigma Aldrich, St. Louis, MO) and mechanically dissociated using a $\mathrm{P}-1000$ pipette.

Brightfield images of each immunopanning step were taken on a Leica DMi8 inverted microscope (Buffalo Grove, IL) at 10x magnification to confirm the attachment of cells of interests. ACs and RGCs were stained with 0.4\% Trypan Blue (\#15250061; Gibco, Waltham, MA) and analyzed on the Countess II Automated Cell Counter (\#AMQAX1000; Invitrogen, Carlsbad, CA) to determine the viability and yield of each cell type per retina for each isolation. Isolated RGCs and ACs were seeded onto 96-well plates (\#655986; Greiner Bio-One, Monroe, SC) and 12mm coverslips (\#1254582; Fisher Scientific, Hampton, NH, USA) at a density of 30,000 cells $/ \mathrm{cm}^{2}$ coated with poly-D-lysine (\#P6407; Sigma-Aldrich, St. Louis, MO, USA) and mouse laminin 1 (\#3400-010-01; Trevigen Gaithersburg, MD). Cells were cultured in a serumfree defined media [37] containing a 1:1 mix of base media of DMEM (\#11960; Invitrogen, Carlsbad, CA) and Neurobasal (\#21103049; Invitrogen, Carlsbad, CA), NS21 supplement (made in house), Brain-Derived Neurotrophic Factor (BDNF) [100 ng/mL] (\#450-02; Peprotech, Rocky Hill, NJ), Ciliary Neurotrophic Factor (CNTF) [20 ng/mL] (\#450-13; Peprotech, Rocky Hill, NJ), and forskolin [8.4ng/mL] (\#F6886; Sigma Aldrich, St. Louis, MO) (DN, 2x Tf/ $\mathrm{F}, 5 \% \mathrm{CO}_{2}$ media). Cytosine $\beta$-D-arabinofuranoside (Ara-C) $[5 \mu \mathrm{M}]$ (\#C6645; Sigma Aldrich, St. Louis, MO) was included in the media to inhibit the growth of glial cells [38]. Cells were cultured in a humidified $5 \% \mathrm{CO}_{2}$ incubator at $37^{\circ} \mathrm{C}$. Half of the media was exchanged for fresh media every two days.

\section{Immunocytochemistry}

RGCs were cultured for 7 days in vitro (DIV) on $12 \mathrm{~mm}$ coverslips before being fixed in $4 \%$ PFA for 15 mins at room temperature (RT) and then permeabilized in $0.1 \%$ Triton X-100 for 5 mins. Cells were then blocked for 1 hour at RT with 5\% BSA and 5\% normal donkey serum. Primary antibodies incubation with guinea pig anti-RBPMS (pan RGC marker) (1:250 dilution, \#1832-RBPMS; PhosphoSolutions, Aurora, CO) and mouse anti-TUJ1 (neuron marker) (1:300 dilution, \#MMS-435P; San Diego, CA) were performed overnight in a moist chamber at $4{ }^{\circ} \mathrm{C}$. Cells were incubated with Cy 3 conjugated secondary antibody (1:1000 dilution, \#706165-148; Jackson ImmunoResearch Laboratories, West Grove, PA) and Alexa Fluor 488 conjugated secondary antibody (1:1000 dilution, \#A-21202; Thermo Fisher Scientific, Waltham, MA) for 1 hour at RT. Stained coverslips were sealed on to glass slides with Prolong Diamond antifade with DAPI (\#P36971; Thermo Fisher Scientific, Waltham, MA). Six images per coverslips, in a fixed $3 \times 2$ grid, were acquired on a Leica DMi8 inverted microscope system (Buffalo Grove, IL). To determine RGC culture purity, RBPMS staining counts were compared to the overlap of co-labeled and only labeled DAPI positive stained cells. Immunocytochemistry of RGC RBPMS staining was performed from three isolations with a total cell count of $\mathrm{n}=11,687$.

\section{Culture condition modifications}

Testing of growth conditions commenced after seeding isolated RGCs and ACs onto 96-well plates for one hour. Three components (base medium, trophic factors/forskolin (Tf/F) concentration, and $\mathrm{CO}_{2}$ concentration) of the previously described (section 2.1) serum-free defined medium culture condition were modified to determine cell viability and neurite growth. First, we varied the base media component for neuronal culture: (Neurobasal (N; see above), 
Neurobasal-A (NA; \#10888022; Invitrogen, Carlsbad, CA), 1:1 mix of DMEM/Neurobasal (DN), 1:1 mix of DMEM/Neurobasal-A (DNA), and 4:1 mix of DMEM/water (DW)). Second, we tested the concentration of Tf/F at two different levels: "1x" concentration (BDNF [50ng/ $\mathrm{mL}], \mathrm{CNTF}[10 \mathrm{ng} / \mathrm{mL}]$, and forskolin $[4.2 \mu \mathrm{g} / \mathrm{mL}]$ ) and " $2 \mathrm{x}$ " concentration (BDNF [100ng/ $\mathrm{mL}$ ], CNTF $[20 \mathrm{ng} / \mathrm{mL}]$, and forskolin $[8.4 \mu \mathrm{g} / \mathrm{mL}]$ ). Third, we adjusted $\mathrm{CO}_{2}$ concentration to two levels (5\% and 10\%). Each permutation was tested, providing a total of 20 different culture conditions. RGCs and ACs were grown in the 20 conditions for 7 DIV with Ara-C, with 50\% of the media exchanged out every other day as above. $\mathrm{pH}$ was monitored using phenol red in the base medium throughout. Culture conditions were analyzed according to the pooled effects of all 20 culture conditions in order to detect large effects of the tested base media, Tf/F concentrations, and $\mathrm{CO}_{2}$ concentrations (see Statistical analysis).

\section{Cell diameter, cell viability, and neurite outgrowth}

Immediately after isolation and 7 DIV, RGCs and ACs were stained with the LIVE/DEAD Viability/Cytotoxicity kit (\#L3224; Invitrogen, Carlsbad, CA) and nuclear stain, Hoechst 33342 (\#H3570, Invitrogen, Carlsbad, CA) to determine live and dead cells and to visualize the neurite morphology of live cells. As a positive control for dead cells, cells were treated with 100\% ice-cold methanol for $5 \mathrm{~min}$ before staining. Cells were incubated in Live-Cell Imaging Solution (\#A14291DJ; Life Technologies, Carlsbad, CA) containing $2 \mu \mathrm{M}$ of calcein-acetomethoxy (calcein-AM), $1 \mu \mathrm{M}$ of ethidium homodimer-1 (EthD-1), and $20 \mu \mathrm{g} / \mathrm{mL}$ of Hoechst 33342 for 30 mins in the dark at $37^{\circ} \mathrm{C}$. Cells were then washed twice and incubated with Live Cell Imaging Solution for imaging on the ImageXpress Pico Automated Cell Imaging System (\#IX Pico; Molecular Devices, San Jose, CA). For each well, images were captured at 10x magnification in a stitched $4 \times 4$ grid to create an acquisition region that covered $75 \%$ of the well. The viability, neurite outgrowth, \# of neurite branches, and \# of neurite processes of each cell were analyzed using CellReporterXpress's (Version 2.5.1.0 Beta; Molecular Devices, San Jose, CA) Cell Scoring: 3 channels and Neurite Tracing built-in analyses. The diameter of a cell was calculated with the formula: diameter $=\sqrt{ }\left(\frac{\text { Area }}{\pi}\right) \times 2$, where the area of the cell was outputted by either the Cell Scoring: 3 channels [39] or Neurite Tracing analysis [40]. Biological replicates for cell viability and neurite outgrowth of each analyzed cell types were Thy $1.2^{+}: \mathrm{n}=5 ; \mathrm{CD} 15^{+}$: $\mathrm{n}=3-4 ; \mathrm{CD}^{+} 7^{+} \mathrm{n}=4-5$.

\section{Puromycin concentration curve}

Adult RGCs were isolated and cultured on 96-wells plates in DN, 2x Tf/F, $5 \% \mathrm{CO}_{2}$ media containing Ara-C for a $24 \mathrm{~h}$ period before puromycin treatment. Ten-fold serial dilutions $\left(10^{4}\right.$ $1 \mathrm{ng} / \mathrm{mL}$ ) of puromycin (\#A1113803, Life Technologies, Carlsbad, CA) were applied to the RGC media for 7 DIV. Half of the media (with puromycin + Ara-C) was exchanged every other day. Viability of puromycin treated cells was determined from RGCs that were stained, imaged, and analyzed on the ImageXpress Pico Automated Cell Imaging System, as described in section $2.4(\mathrm{n}=3)$.

\section{Statistical analysis}

Statistical analyses were performed using Prism (GraphPad, La Jolla, CA). Two-tailed t-tests were used to compare $\mathrm{CO}_{2}$ concentrations and $\mathrm{Tf} / \mathrm{F}$ concentrations. One-way ANOVAs using Tukey's multiple comparisons test were used to compare among base media. Statistical significance of the experimental data was described as ${ }^{*}=\mathrm{p}<0.05 ;^{* *}=\mathrm{p}<0.01 ;^{* * *}=\mathrm{p}<0.001$; ${ }^{* * * *}=\mathrm{p}<0.0001$. Data are presented as mean \pm SEM. 


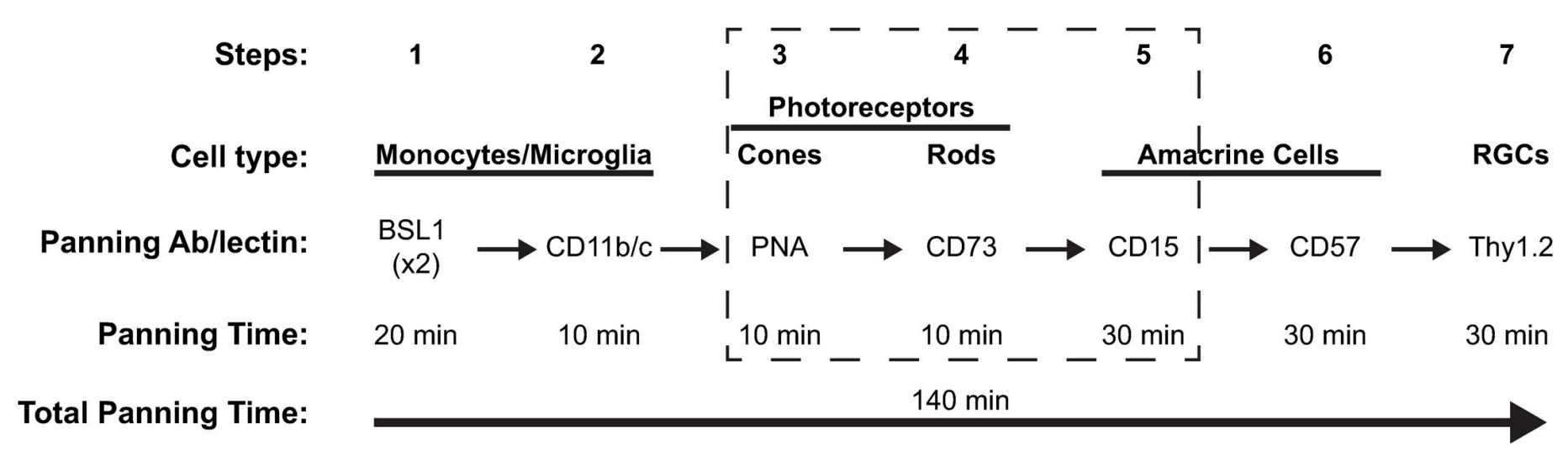

Fig 1. Schematic diagram of the 7-step immunopanning method to isolate adult mice ACs and RGCs. Following retinal dissociation, the cell suspension is panned through a series of plates coated with lectins and antibodies adhering cells of interest to be either negatively or positively selected. The initial four negative panning steps allow for the removal of monocytes, microglia, and photoreceptors from the retinal cell suspension. Positive panning (cells of interest to be collected) steps \#5 and \#6 select for ACs, while positive panning step \#7 selects for RGCs. The total immunopanning time is 140 minutes. The dotted line box highlights three new steps that are improvements in the technique to isolate AC and RGCs successfully.

https://doi.org/10.1371/journal.pone.0242426.g001

\section{Results}

\section{RGC isolation from adult mice using a 7-step immunopanning method}

We adapted our previous 4-step immunopanning method to isolate RGCs from adult mice by adding three additional steps to improve RGC purity and yield (Fig 1). To debulk the retinal suspension and allow for improved dilution and dispersion of cells in subsequent panning steps, we removed cone and rod photoreceptors with negative selection plates coated with PNA [41] and anti-CD73 [42], respectively. To further deplete ACs in order to allow for improved binding of RGCs to Thy1.2 antibody in the final step, we added a selection plate coated with anti-CD15 [43] just prior to the existing anti-CD57 plate. We did not modify the other steps (negative panning with BSL1 and anti-CD11b/c and positive selection with antiThy 1.2). The three additional steps increased panning time by 50 minutes, resulting in a total time of 140 minutes. Despite this increased time, the new 7-step immunopanning technique produced large, circular, (Fig 2A) and healthy (Fig 2B; $91.1 \pm 1.0 \%$ viable) Thy1. $2^{+}$cells at high yields (Fig 2B; 49,358 $\pm 6,655$ cells per retina) consistent with our prior study [36]. Immunostaining of Thy $1.2^{+}$cells with RBPMS revealed that these cells are highly enriched for RGCs, reaching $85.4 \pm 1.7 \%$ purity.

\section{RGC culture, optimization of culture conditions, and potential use as a screening assay}

Injury and stress inflicted on cells by enzymatic and mechanical dissociation during isolation has limited prior attempts to culture adult RGCs $[44,45]$. Nevertheless, because of the high yield and viability of our isolated RGCs, we sought to determine conditions that could allow for their culture (Fig 3). RGCs were treated for 7 days according to a series of 20 possible permutations of culture conditions. These comprised 5 different base media, 2 concentrations of $\mathrm{Tf} / \mathrm{F}$, and 2 concentrations of $\mathrm{CO}_{2}(\mathrm{n}=5$; see Methods). Viability was good across all culture conditions, with an overall viability of $50.0 \pm 2.3 \%$ at 7 DIV. However, Live/Dead/nuclear analysis of RGC viability revealed subtle differences (Table 1). For example, base medium DNA $(34.4 \pm 5.2 \%)$ significantly $(\mathrm{p}=0.037)$ decreased RGC viability compared to the base medium $\mathrm{N}(62.8 \pm 6.6 \%)$. RGC viability was not affected by changes in Tf/F or $\mathrm{CO}_{2}$. Surprisingly, we found that $\sim 10-25 \%$ of RGCs extended neurites at 7 DIV. Neurites were either single or multi/ 
A

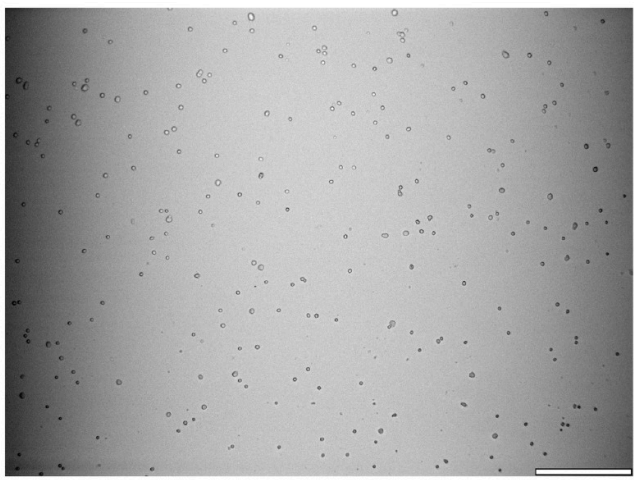

C

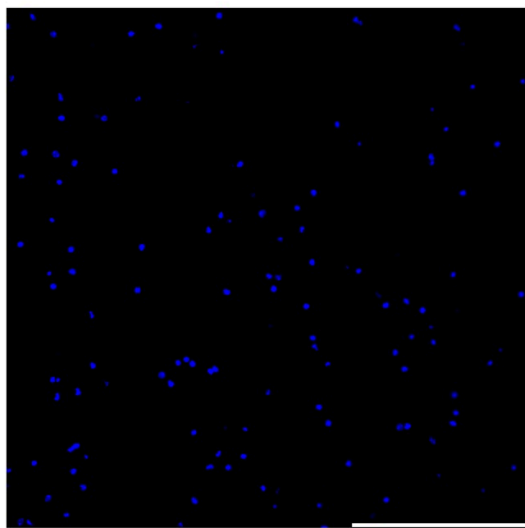

B

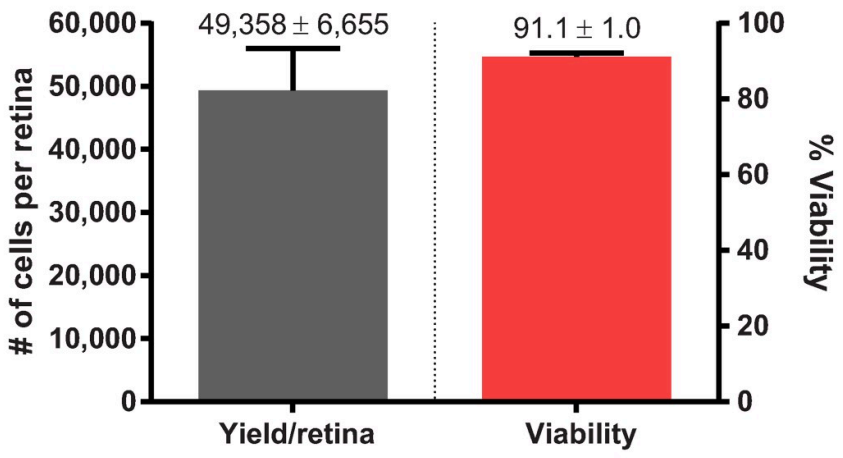

$\mathbf{E}$

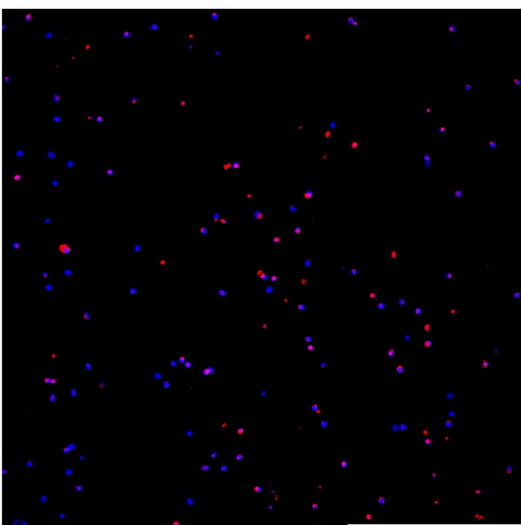

Fig 2. Characterization of purified RGCs isolated from adult mice. (A) Brightfield image (10x) of panning step \#7 of Thyl.2 ${ }^{+}$adherent cells after washes. (B) The 7 -step immunopanning method to isolate Thy $1.2^{+}$cells yields $49,358 \pm 6,655$ cells per retina with a $91.1 \pm 1.0 \%$ cell viability $(\mathrm{n}=5)$. Thy1.2 ${ }^{+}$cells, cultured for 7 DIV, immunostained for an RGC marker, RBPMS (D), and nuclear stain, DAPI (C). RBPMS co-stained $85.4 \pm 1.7 \%$ of DAPI positive cells in (E) merged image ( $\mathrm{n}=11,687$ ). Scale bar $=200 \mu \mathrm{m}$.

https://doi.org/10.1371/journal.pone.0242426.g002

complex (Fig 4A), in some cases reaching $>500 \mu \mathrm{m}$ in length (Fig 4B). Neurites were also seen from cultured RGCs isolated from aged mice ( $>10$ months; example in Fig 4C and 4D). Neurite analysis, across the same culture permutations, showed a generally improved performance of base medium DNA against all other media, in particular when compared to base medium $\mathrm{N}$ $(\mathrm{p}<0.001$; Table 1$)$. Thus, the base medium with the worst cell viability, DNA, had the highest percentage of live RGCs containing neurite processes (23.8 $\pm 1.7 \%)$. The converse was true for base medium $\mathrm{N}$, which had the best cell viability but the lowest percentage of live RGCs containing neurite processes $(14.1 \pm 1.6 \% ; \mathrm{p}=0.0018)$. Additionally, culturing in $5 \% \mathrm{CO}_{2}$ $(20.7 \pm 1.5 \%)$ resulted in a higher percentage of live RGCs containing neurite processes than $10 \% \mathrm{CO}_{2}(15.0 \pm 1.5 \% ; \mathrm{p}=0.026)$. No differences were observed in the mean RGC outgrowth length, \# of branches, and \# of processes according to culture conditions. Thus, the choice of base medium and $\mathrm{CO}_{2}$ concentration appears to be a determinant of the number of RGCs that extend neurites, but not of the quality and type of these neurites.

Since adult RGCs in culture can be an invaluable tool for future pharmacological and genetic studies, we tested if the application of puromycin, which is widely used as a screening assay, consistently reduced the viability of cultured RGCs in a dose-dependent manner (Fig 5) $[46,47]$. Indeed, the $\mathrm{IC}_{50}$ of the RGC puromycin kill curve was $72.9 \mathrm{ng} / \mathrm{mL}$, which is consistent with other mammalian cells used in screening assays [48], and the three trials showed minimal variability among them. Together, the 7-step immunopanning technique is gentle enough to 


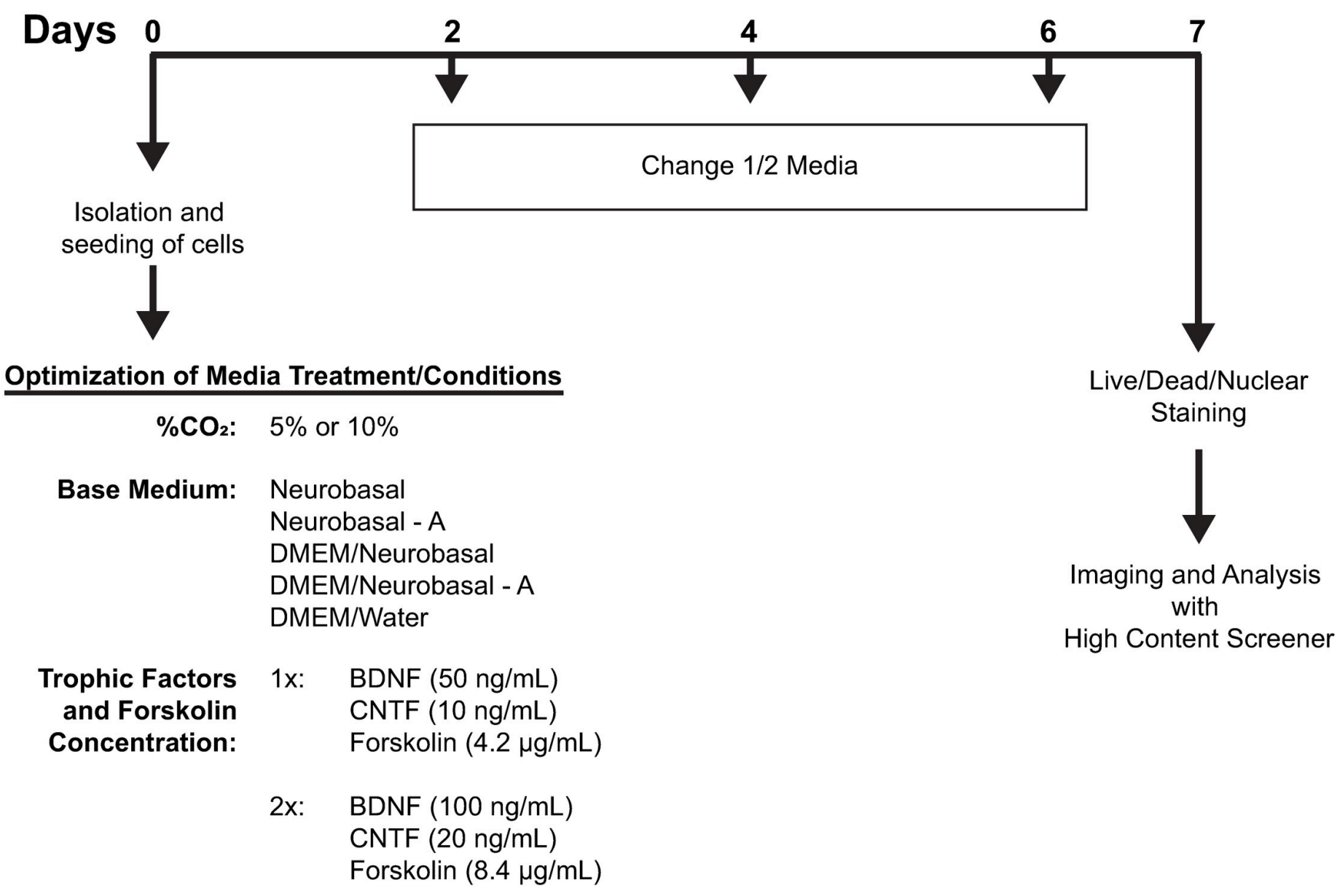

Fig 3. Schematic of study design optimizing culture conditions for adult mouse RGCs and ACs. Post isolation and seeding of RGCs and ACs, cells are treated with 20 different potential culture conditions for 7 days. Half the media is exchanged for fresh media containing the same components every other day. At the end of 7 DIV, cells are stained, imaged, and analyzed using a high content screener.

https://doi.org/10.1371/journal.pone.0242426.g003

allow for the culture of adult mice RGCs that extend neurites. Furthermore, these cultures can likely be used as an in vitro screening tool for studies that requires enrich populations of RGCs from adult mice.

\section{AC culture and optimization of culture conditions}

As a byproduct of the 7-step immunopanning method to isolate RGCs, two populations of ACs $\left(\mathrm{CD} 15^{+}\right.$and $\left.\mathrm{CD} 57^{+}\right)$were isolated $(\mathrm{n}=5)$. Using the same approach as above, we used these populations to determine if adult ACs can also be cultured, in vitro. Similar to RGCs, isolated $\mathrm{CD} 15^{+}$and $\mathrm{CD} 57^{+}$cells were large and circular (Fig 6A and 6B), with viability greater than $75 \%$ (Fig 6C and 6D). The yield of CD15 ${ }^{+}$and $\mathrm{CD}^{+} 7^{+}$cells per retina were 14,717 $\pm 3,717$ and 25,471 $\pm 3,447$, respectively, lower than the RGC isolation yield. After 7 days, cultured adult $\mathrm{CD} 15^{+}$and $\mathrm{CD}_{57}{ }^{+}$are viable and have to ability to extend neurites (Fig 6E and 6F). Comparable to cultured adult RGCs, base medium DNA reduced CD $15^{+}$viability $(51.8 \pm 2.1 \%)$ when compared to the best-performing base medium, which was again $\mathrm{N}$ $(69.8 \pm 2.1 \% ; \mathrm{p}=0.0025$; Table 2$)$. CD $15^{+}$cells were significantly more viable in $5 \% \mathrm{CO}_{2}$ $(65.3 \pm 2.3 \%)$, compared to cells cultured in $10 \% \mathrm{CO}_{2}(57.4 \pm 1.8 \% ; \mathrm{p}=0.0088)$. Similar to 
Table 1. Thy $1.2^{+}$culture conditions, viability and neurite analyses.

\begin{tabular}{|c|c|c|c|c|c|}
\hline & \multirow{2}{*}{\begin{tabular}{|l|} 
Viability \\
$\%$ alive \\
\end{tabular}} & \multicolumn{4}{|l|}{ Neurite analysis } \\
\hline & & $\%$ cells w/processes & Mean outgrowth length $(\mu \mathrm{m}) /$ cell & Mean \# of branches/cell & Mean \# processes/cell \\
\hline \multicolumn{6}{|c|}{ Base Medium } \\
\hline $\mathrm{N}^{\mathrm{a}}$ & $62.8 \pm 6.6$ & $14.1 \pm 1.6$ & $94.6 \pm 8.3$ & $1.2 \pm 0.2$ & $1.4 \pm 0.0$ \\
\hline $\mathrm{NA}^{\mathrm{b}}$ & $54.5 \pm 5.8$ & $16.9 \pm 1.1$ & $103.4 \pm 7.3$ & $1.4 \pm 0.2$ & $1.5 \pm 0.0$ \\
\hline $\mathrm{DN}$ & $50.5 \pm 8.1$ & $19.0 \pm 1.8$ & $108.6 \pm 8.6$ & $1.6 \pm 0.2$ & $1.6 \pm 0.1$ \\
\hline $\mathrm{DNA}^{\mathrm{c}}$ & $34.4 \pm 5.2^{\text {a } *}$ & $23.8 \pm 1.7^{\mathrm{a} * * \mathrm{~b} *}$ & $103.1 \pm 6.7$ & $1.5 \pm 0.2$ & $1.6 \pm 0.0$ \\
\hline DW & $47.9 \pm 5.7$ & $15.5 \pm 1.4^{\mathrm{c} * *}$ & $106.4 \pm 7.4$ & $1.6 \pm 0.2$ & $1.5 \pm 0.1$ \\
\hline \multicolumn{6}{|c|}{ Trophic factors/Forskolin (Tf/F) Concentration } \\
\hline $1 \mathrm{x}$ & $53.4 \pm 4.1$ & $18.2 \pm 1.2$ & $104.2 \pm 6.1$ & $1.4 \pm 0.1$ & $1.6 \pm 0.1$ \\
\hline $2 \mathrm{x}$ & $51.4 \pm 3.4$ & $17.5 \pm 1.0$ & $102.3 \pm 7.4$ & $1.5 \pm 0.2$ & $1.5 \pm 0.0$ \\
\hline \multicolumn{6}{|l|}{$\% \mathrm{CO}_{2}$} \\
\hline 5 & $53.7 \pm 4.1$ & $20.7 \pm 1.5^{*}$ & $106.1 \pm 9.1$ & $1.5 \pm 0.3$ & $1.6 \pm 0.1$ \\
\hline 10 & $47.4 \pm 4.0$ & $15.0 \pm 1.5$ & $100.3 \pm 5.7$ & $1.4 \pm 0.2$ & $1.5 \pm 0.0$ \\
\hline
\end{tabular}

Data are expressed as mean \pm SE.

Superscript letters are significant differences between base medium groups.

Symbols ${ }^{*},{ }^{* *}$ are levels of significance at $\mathrm{p}<0.05$ and $\mathrm{p}<0.01$, respectively.

https://doi.org/10.1371/journal.pone.0242426.t001

adult RGCs, the percentage of $\mathrm{CD}^{+} 5^{+}$ACs with neurite processes was significantly increased in base medium DNA compared to base medium $\mathrm{N}(\mathrm{p}<0.001) .5 \% \mathrm{CO}_{2}$ significantly increased both the percentage of $\mathrm{CD}^{+} 5^{+}$cells containing neurite processes as well as the number of processes per cell ( $\mathrm{p}=0.0064$ for both). However, $\mathrm{CD} 15^{+}$cells had significantly $(\mathrm{p}<0.0001)$ fewer branches and shorter neurites than $\mathrm{CD}^{2} 7^{+}$cells (compare Tables 2 and 3 ). The two concentrations of Tf/F did not affect $\mathrm{CD} 15^{+}$viability or neurite extension. Finally, media conditions did not affect $\mathrm{CD} 7^{+}$cell viability or neurite extensions (Table 3). These results demonstrate that the 7-step immunopanning method can be adapted for successful isolation and culture of multiple cell types from a single tissue.

\section{Diameter diversity of isolated and cultured RGCs and ACs}

The somas of the various subpopulations of RGCs $[49,50]$ and ACs [51,52] range widely in diameter. Soma diameters of live Thy $1.2^{+}, \mathrm{CD} 15^{+}$, and $\mathrm{CD} 57^{+}$cells were therefore measured immediately following isolation ( $\mathrm{n}=5$ for each cell type) and at 7 DIV to determine if isolations of these cell populations are diverse. The average soma diameters of recently isolated (0 DIV) Thy1 $12^{+}, \mathrm{CD} 15^{+}$, and $\mathrm{CD} 57^{+}$cells are $8.5,8.7$, and $8.6 \mu \mathrm{m}$, respectively. However, all three cell populations varied widely in soma diameter, showing a range of $4-36 \mu \mathrm{m}$ with a unimodal distribution where the majority of the cell diameters range from 4-15 $\mu \mathrm{m}$ (Fig 7A7C). When culture times for all three cell populations extended to 7 DIV, the live cell soma diameter broadened to 5-41 $\mu \mathrm{m}$ in diameter. Furthermore, instead of a unimodal distribution, all three cell populations had a bimodal distribution at $7 \mathrm{DIV}$, showing both small and large diameter somas (Fig 7A-7C). Lastly, Thy $1.2^{+}, \mathrm{CD} 15^{+}$, and $\mathrm{CD} 57^{+}$cells with neurites cultured for 7 DIV have average soma diameters similar to all live cells cultured for 7 DIV. The range of the diameters of each neuron population with neurites (Fig 7D-7F) resembles the right hump of the corresponding cell population bimodal distribution. This may indicate that the right hump contains healthier neurons compared to the left hump, which may represent dying neurons. 

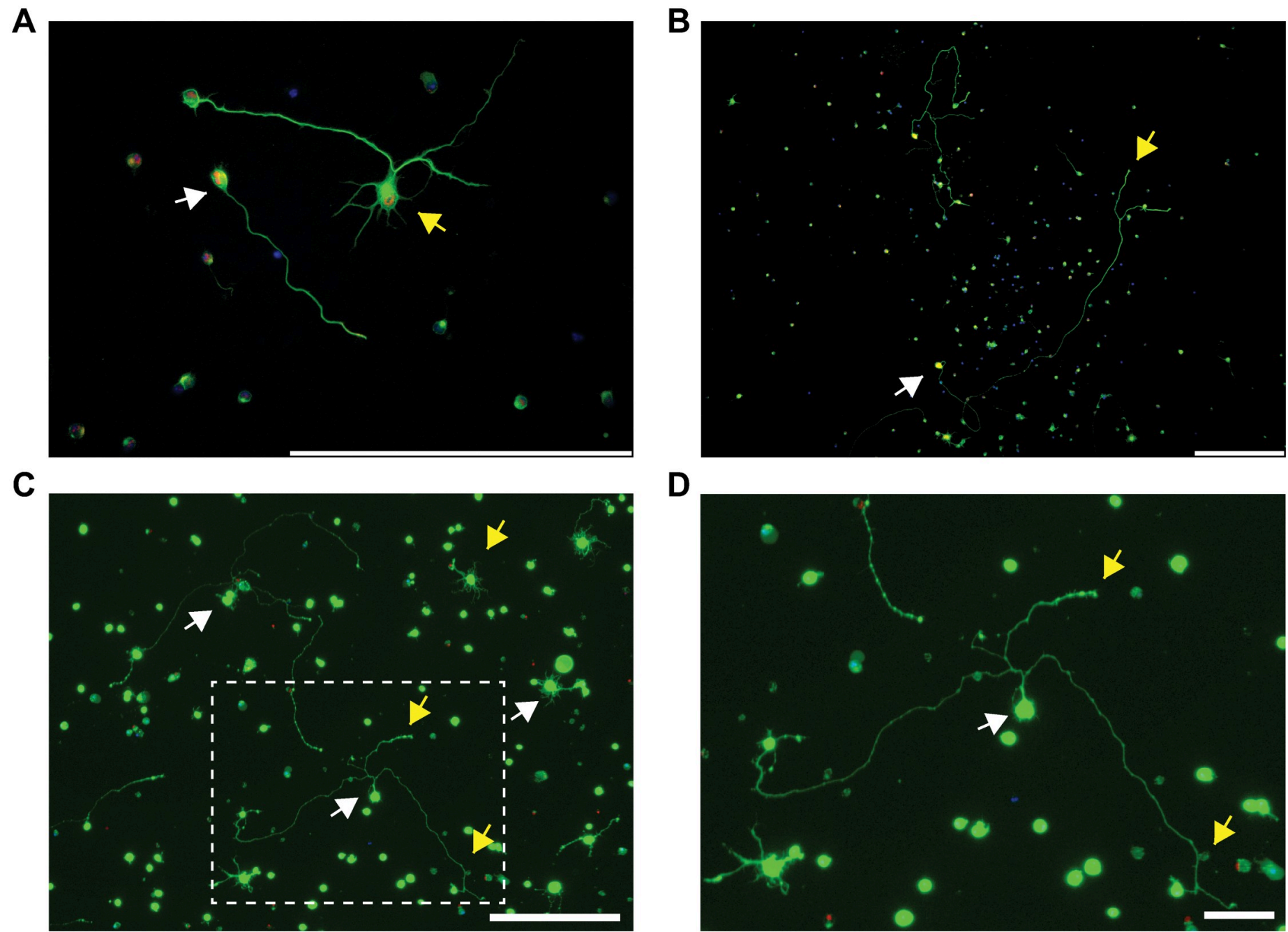

D

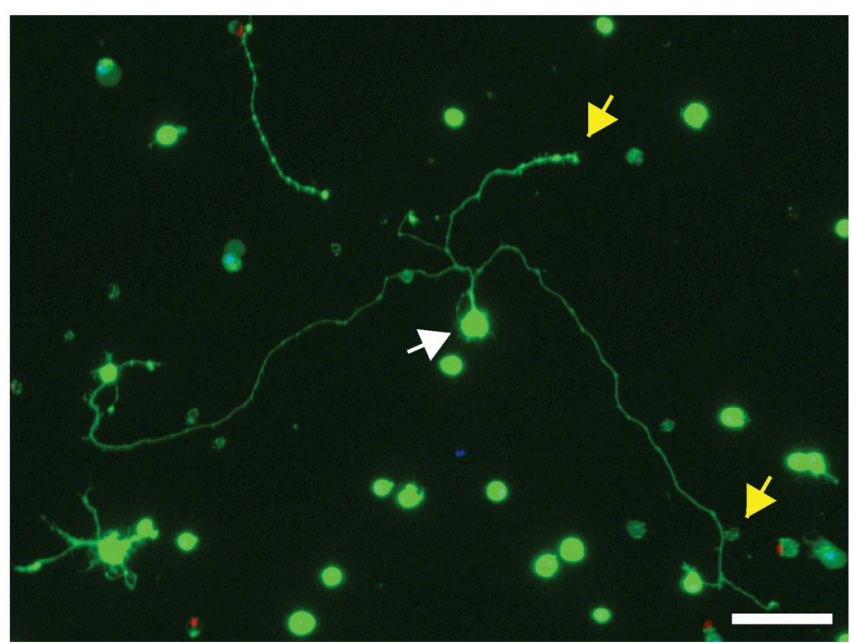

Fig 4. Neurite extensions from cultured adult mouse RGCs at 7 DIV. (A,B) Adult mouse RGCs immunostained for RBPMS (red), Tuj1 (green), and DAPI (blue) (Scale bar $=200 \mu \mathrm{m}$ ). (A) RGCs can extend single (white arrow) and multi/complex neurites (yellow arrow). (B) Example of long $(>500 \mu \mathrm{m})$ RGC neurite extension (yellow arrow) from the soma (white arrow) $($ Scale bar $=200 \mu \mathrm{m})$. (C) Live (green)/Dead (red)/nuclear (blue) staining of RGCs isolated from aged adult mice older than 10 months are viable (white arrows) and extend neurites (yellow arrows) (Scale bar $=200 \mu \mathrm{m})$. (D) Zoom-in of the boxed area in C (Scale bar $=50 \mu \mathrm{m})$.

https://doi.org/10.1371/journal.pone.0242426.g004

\section{Discussion}

Mature CNS neurons are post-mitotic, non-dividing cells that are extremely susceptible to injury and death, thus are limited in cell culture applications [53, 54]. Using a 7-step immunopanning technique adapted from our original protocol, we have effectively isolated RGCs from adult mouse retinas with high purity and yield. Importantly, the isolation yield approached the theoretical maximum of RGCs from mouse retina, which is a substantial improvement over the existing literature, in which attempts at adult RGC isolation in rats yielded approximately $10-25 \%$ of the theoretical cell yield $[32,35,55]$. Additionally, by adjusting the procedure, we were also able to extract two subpopulations of ACs during the same isolation. The week-long cultivation of all three neuron populations revealed excellent viability. Finally, up to $\sim 25 \%$ of healthy cells extend single or multiple neurite extensions of variable lengths, with some neurites exceeding $500 \mu \mathrm{m}$. Optimization of the culture conditions for RGCs and ACs identified inverse response differences between cell viability and neurite outgrowth. As these cells are 


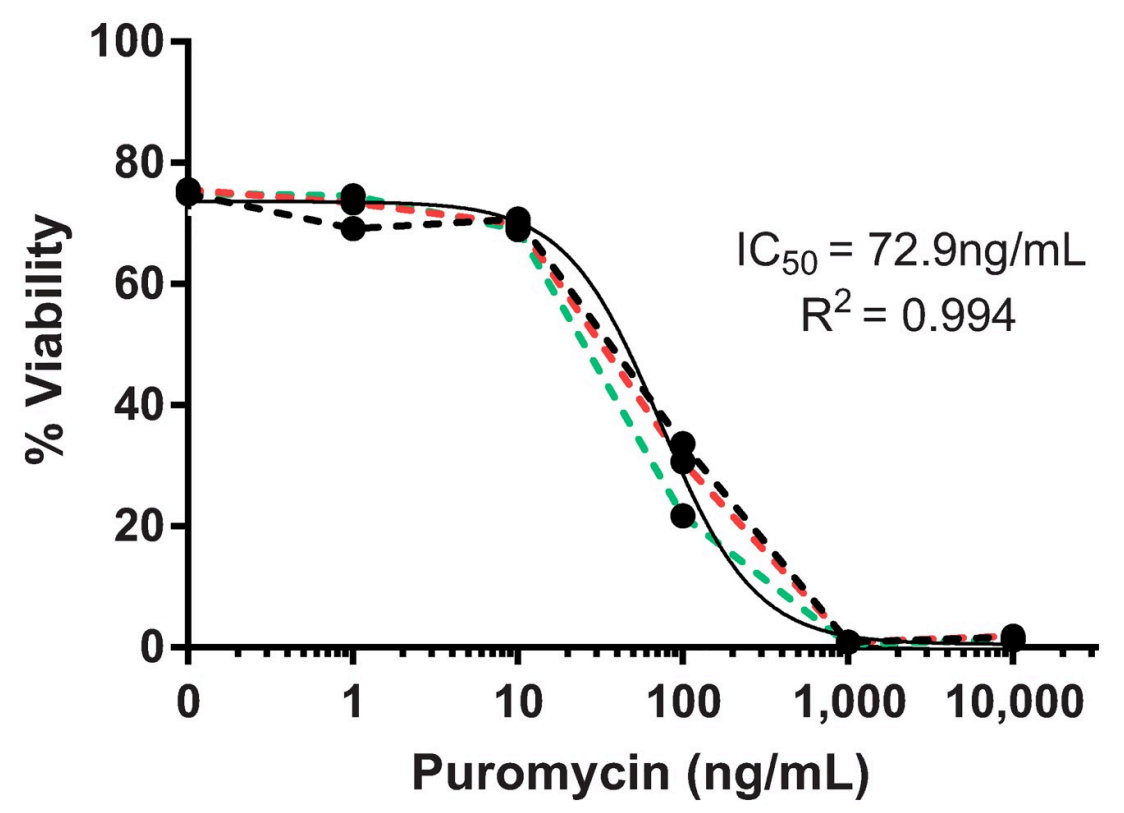

Fig 5. Adult RGC puromycin concentration-response curve after 7 DIV. Varying treatment concentrations of puromycin $(1,10,100,1,000,10,000 \mathrm{ng} / \mathrm{mL})$ decreased RGC viability in a concentration-dependent manner. Dotted black, red, and green lines represent the individual biological replicates $(n=3)$. The solid black line represents the nonlinear regression plot of the three replicates.

https://doi.org/10.1371/journal.pone.0242426.g005

isolated from adult tissue, this technique allows for the successful culturing of enriched populations of mature neurons, where previously purified neuronal cultures were limited to neonatal and iPSCs derived neurons.

It is essential to use adult neuronal in vitro models in parallel with other experimental models to further delineate function, aging, and disease pathogenesis of CNS neurons [56]. Neurons derived from neonates and iPSCs are easily generated in large quantities and can be cultured with excellent viability with extensive neurite outgrowth $[3,6]$. However, prior to isolation, these neurons are limited to genetic manipulation as well by their neuronal immaturity and epigenetic gap [57]. The successful cultivation of adult RGC and AC neurons described in this paper fills those gaps, allowing use in conjunction with a much wider range of experimental models. For example, mature neurons can be cultured from aged-matched animals correlating to the ages used in parallel with in vivo studies. Additionally, experimental manipulation using genetic, pharmacological, and mechanical interventions on in vivo or ex vivo models can be performed prior to neuronal isolation. These neurons can subsequently be cultured to be further tested for their responses to different stimuli, retaining epigenetic modifications that were gained in vivo before cell isolation. Thus, adult neuronal cultures are likely to be more adept at addressing questions related to the neurobiology of aging, disease, and injury.

RGCs [21, 50] and ACs [25] are both heterogeneous and include multiple subtypes. A few of these subtypes have neuroprotective and regenerative properties, which may represent the live cells in our neuronal cultures $[12,58,59]$. The broad ranges in diameters of isolated and cultured Thy $1.2^{+}, \mathrm{CD} 15^{+}$, and $\mathrm{CD} 57^{+}$cells, indicates diverse populations were collected. By using two well-known pan-RGC markers to first isolate (Thy1.2) [2] at the theoretical yield of mouse RGCs and then validate high purity with RBPMS [19], we can assume that we have captured many subtypes of RGCs. Although our technique is able to successfully isolate RGCs, a specific exogenous pan-ACs marker has not yet been identified for isolation use. However, at least two AC markers specific to large populations of cells have been identified $[12,43,60]$. In 
A

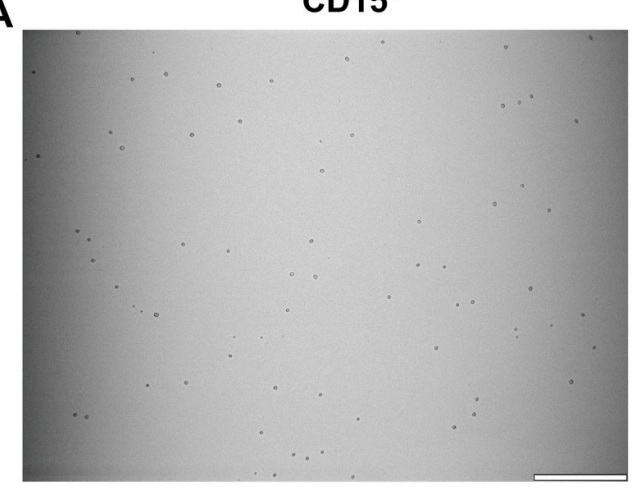

C

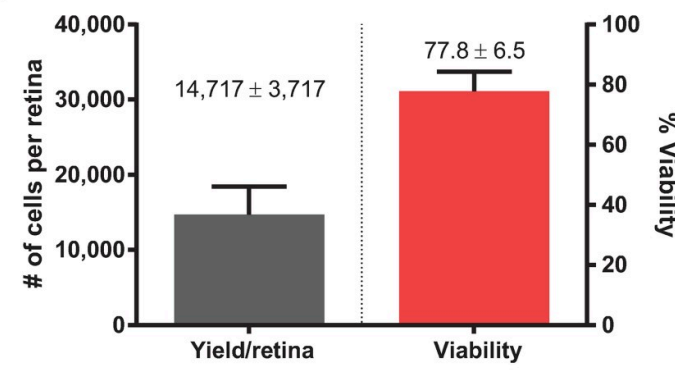

E

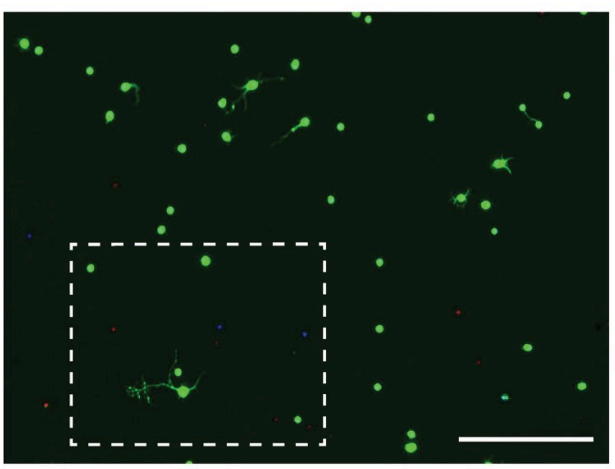

G

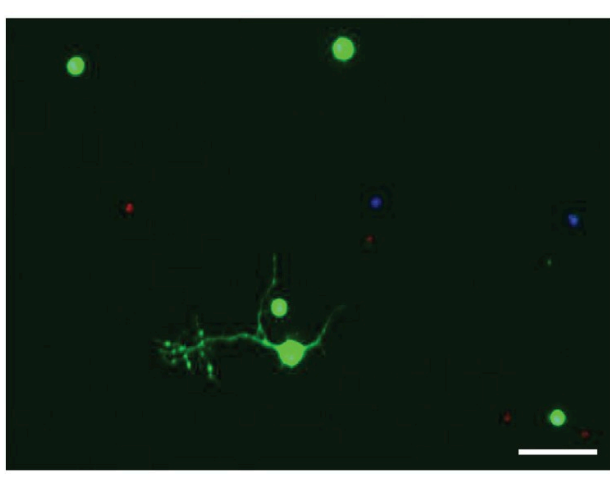

B

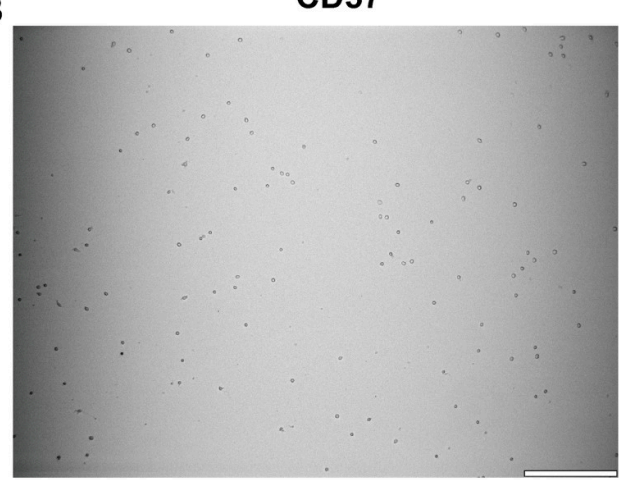

D

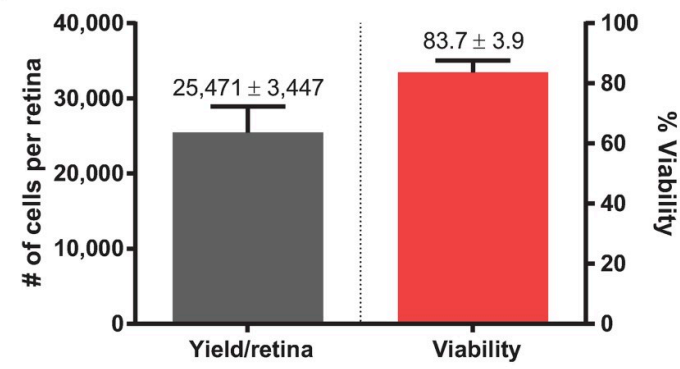

$\mathbf{F}$

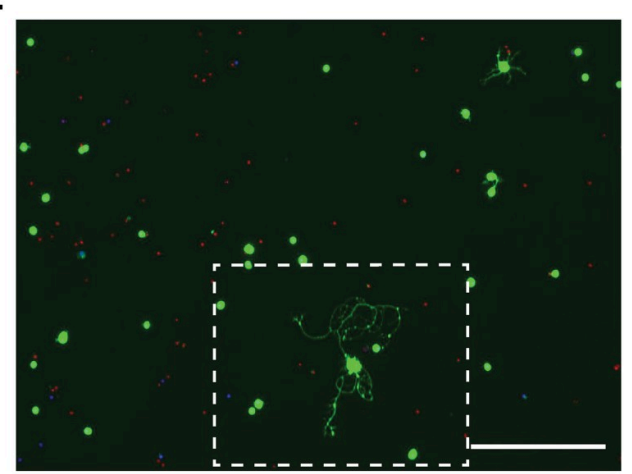

$\mathbf{H}$

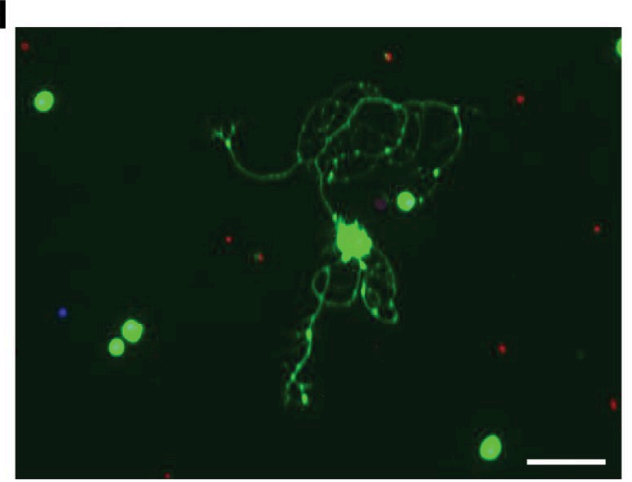

Fig 6. Isolation and culture of $\mathrm{CD}^{+}{ }^{+}$and $\mathrm{CD}^{+} 7^{+} \mathrm{ACs}$ from adult mice. Brightfield (10x) images of attached (A) CD15 ${ }^{+}$and (B) $\mathrm{CD} 57^{+}$cells to positive panning plates after non-adherent cell washes (Scale bar $=200 \mu \mathrm{m}$ ). Collected cell yield and viability of $(\mathrm{C})$ $\mathrm{CD}^{+} 5^{+}$and $(\mathrm{D}) \mathrm{CD}^{+} 7^{+}$cells after immunopanning $(\mathrm{n}=5)$. Live/Dead/nuclear images of $(\mathrm{E}) \mathrm{CD}^{+} 5^{+}$and $(\mathrm{F}) \mathrm{CD}^{+} 7^{+}$cells after 7 DIV (Scale bar $=200 \mu \mathrm{m}) .(\mathrm{G}, \mathrm{H})$ Zoom-in of the boxed areas in $\mathrm{E}$ and $\mathrm{F}$, respectively (Scale bar $=50 \mu \mathrm{m})$.

https://doi.org/10.1371/journal.pone.0242426.g006 
Table $2 . \mathrm{CD}^{+} 5^{+}$culture conditions, viability and neurite analyses.

\begin{tabular}{|c|c|c|c|c|c|}
\hline & \multirow{2}{*}{\begin{tabular}{|l|} 
Viability \\
$\%$ alive \\
\end{tabular}} & \multicolumn{4}{|l|}{ Neurite analysis } \\
\hline & & $\%$ cells w/processes & Mean outgrowth length $(\mu \mathrm{m}) /$ cell & Mean \# of branches/cell & Mean \# processes/cell \\
\hline \multicolumn{6}{|c|}{ Base Medium } \\
\hline $\mathrm{N}^{\mathrm{a}}$ & $69.8 \pm 2.1$ & $12.4 \pm 1.0$ & $57.5 \pm 3.3$ & $0.6 \pm 0.0$ & $1.4 \pm 0.1$ \\
\hline $\mathrm{NA}^{\mathrm{b}}$ & $69.3 \pm 1.5$ & $16.7 \pm 0.8^{\mathrm{a} * *}$ & $68.3 \pm 5.0$ & $0.8 \pm 0.1$ & $1.4 \pm 0.0$ \\
\hline $\mathrm{DN}^{\mathrm{c}}$ & $61.0 \pm 4.6$ & $17.0 \pm 0.6^{\mathrm{a} * *}$ & $67.6 \pm 5.5$ & $0.9 \pm 0.2$ & $1.5 \pm 0.0$ \\
\hline $\mathrm{DNA}^{\mathrm{d}}$ & $51.8 \pm 1.8^{\mathrm{a} * * \mathrm{~b} * *}$ & $22.0 \pm 0.6^{\mathrm{a} * * * * \mathrm{~b} * * \mathrm{c} * *}$ & $67.7 \pm 7.4$ & $0.9 \pm 0.2$ & $1.5 \pm 0.0$ \\
\hline DW & $56.5 \pm 2.6^{\mathrm{a} * \mathrm{~b} *}$ & $17.2 \pm 0.8^{\mathrm{a} * * \mathrm{~d} * *}$ & $72.8 \pm 5.1$ & $1.0 \pm 0.2$ & $1.5 \pm 0.0$ \\
\hline \multicolumn{6}{|c|}{ Trophic factors/Forskolin (Tf/F) Concentration } \\
\hline $1 \mathrm{x}$ & $62.3 \pm 3.1$ & $16.9 \pm 0.3$ & $66.1 \pm 2.8$ & $0.8 \pm 0.1$ & $1.5 \pm 0.0$ \\
\hline $2 \mathrm{x}$ & $59.9 \pm 1.6$ & $17.1 \pm 0.6$ & $68.2 \pm 4.4$ & $0.8 \pm 0.2$ & $1.4 \pm 0.0$ \\
\hline \multicolumn{6}{|l|}{$\% \mathrm{CO}_{2}$} \\
\hline 5 & $65.3 \pm 2.3^{* *}$ & $20.6 \pm 1.2^{* *}$ & $68.2 \pm 3.0$ & $0.9 \pm 0.0$ & $1.5 \pm 0.0^{* *}$ \\
\hline 10 & $57.4 \pm 1.8$ & $12.1 \pm 1.0$ & $65.4 \pm 7.2$ & $0.7 \pm 0.3$ & $1.3 \pm 0.0$ \\
\hline
\end{tabular}

Data are expressed as mean \pm SE.

Superscript letters are significant differences between base medium groups.

Symbols ${ }^{*},{ }^{* *},{ }^{* * *}$ are levels of significance at $\mathrm{p}<0.05, \mathrm{p}<0.01$, and $\mathrm{p}<0.0001$, respectively.

https://doi.org/10.1371/journal.pone.0242426.t002

a mouse retina, $\mathrm{CD} 15$ is localized in two populations of ACs, containing both small and large soma diameters [43], resembling our bimodal cell diameter distribution (Fig 7B). Isolation of adult ACs using these two markers yields a total of 40,000 cells per retina $(<1 \%$ of the retina population), a minority of total ACs [29]. When culturing the two subpopulations of adult ACs, differences between the two cell types were exposed. Interestingly, $\mathrm{CD} 15^{+} \mathrm{ACs}$ and adult RGCs shared similar characteristics with regard to cell survival and neurite outgrowth according to culture conditions (see below). In contrast, mature $\mathrm{CD} 57^{+}$cells' survival was nondependent to exogenous changes in culture conditions. This may reflect the observation that $\mathrm{CD} 7^{+}$ACs may be resistant to neurodegeneration [12]. Further characterization of these

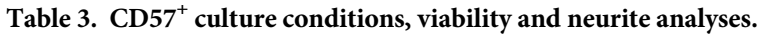

\begin{tabular}{|c|c|c|c|c|c|}
\hline & \multirow{2}{*}{\begin{tabular}{|l|} 
Viability \\
$\%$ alive \\
\end{tabular}} & \multicolumn{4}{|l|}{ Neurite analysis } \\
\hline & & $\%$ cells w/processes & Mean outgrowth length $(\mu \mathrm{m}) /$ cell & Mean \# of branches/cell & Mean \# processes/cell \\
\hline \multicolumn{6}{|c|}{ Base Medium } \\
\hline $\mathrm{N}$ & $42.8 \pm 6.7$ & $11.4 \pm 1.0$ & $95.6 \pm 7.5$ & $1.3 \pm 0.2$ & $1.5 \pm 0.0$ \\
\hline NA & $39.8 \pm 8.3$ & $11.5 \pm 0.6$ & $89.0 \pm 3.8$ & $1.3 \pm 0.1$ & $1.5 \pm 0.0$ \\
\hline $\mathrm{DN}$ & $33.8 \pm 5.5$ & $11.5 \pm 0.3$ & $77.9 \pm 4.4$ & $1.1 \pm 0.1$ & $1.5 \pm 0.1$ \\
\hline DNA & $26.7 \pm 5.4$ & $13.6 \pm 0.9$ & $82.3 \pm 10.7$ & $1.2 \pm 0.2$ & $1.5 \pm 0.1$ \\
\hline DW & $23.5 \pm 4.8$ & $11.9 \pm 1.4$ & $100.4 \pm 15.7$ & $1.6 \pm 0.4$ & $1.5 \pm 0.1$ \\
\hline \multicolumn{6}{|c|}{ Trophic factors/Forskolin (Tf/F) Concentration } \\
\hline $1 \mathrm{x}$ & $38.1 \pm 3.0$ & $11.4 \pm 0.9$ & $86.5 \pm 9.4$ & $1.3 \pm 0.2$ & $1.5 \pm 0.0$ \\
\hline $2 \mathrm{x}$ & $37.5 \pm 3.3$ & $12.6 \pm 0.6$ & $91.6 \pm 5.1$ & $1.3 \pm 0.1$ & $1.5 \pm 0.1$ \\
\hline \multicolumn{6}{|c|}{$\% \mathrm{CO}_{2}$} \\
\hline 5 & $34.2 \pm 2.4$ & $12.3 \pm 0.5$ & $84.6 \pm 7.9$ & $1.2 \pm 0.2$ & $1.5 \pm 0.0$ \\
\hline 10 & $40.1 \pm 2.1^{\dagger}$ & $11.0 \pm 1.3$ & $91.6 \pm 8.2$ & $1.3 \pm 0.2$ & $1.4 \pm 0.1$ \\
\hline
\end{tabular}

Data are expressed as mean \pm SE.

${ }^{\dagger} \mathrm{p}=0.07$.

https://doi.org/10.1371/journal.pone.0242426.t003 

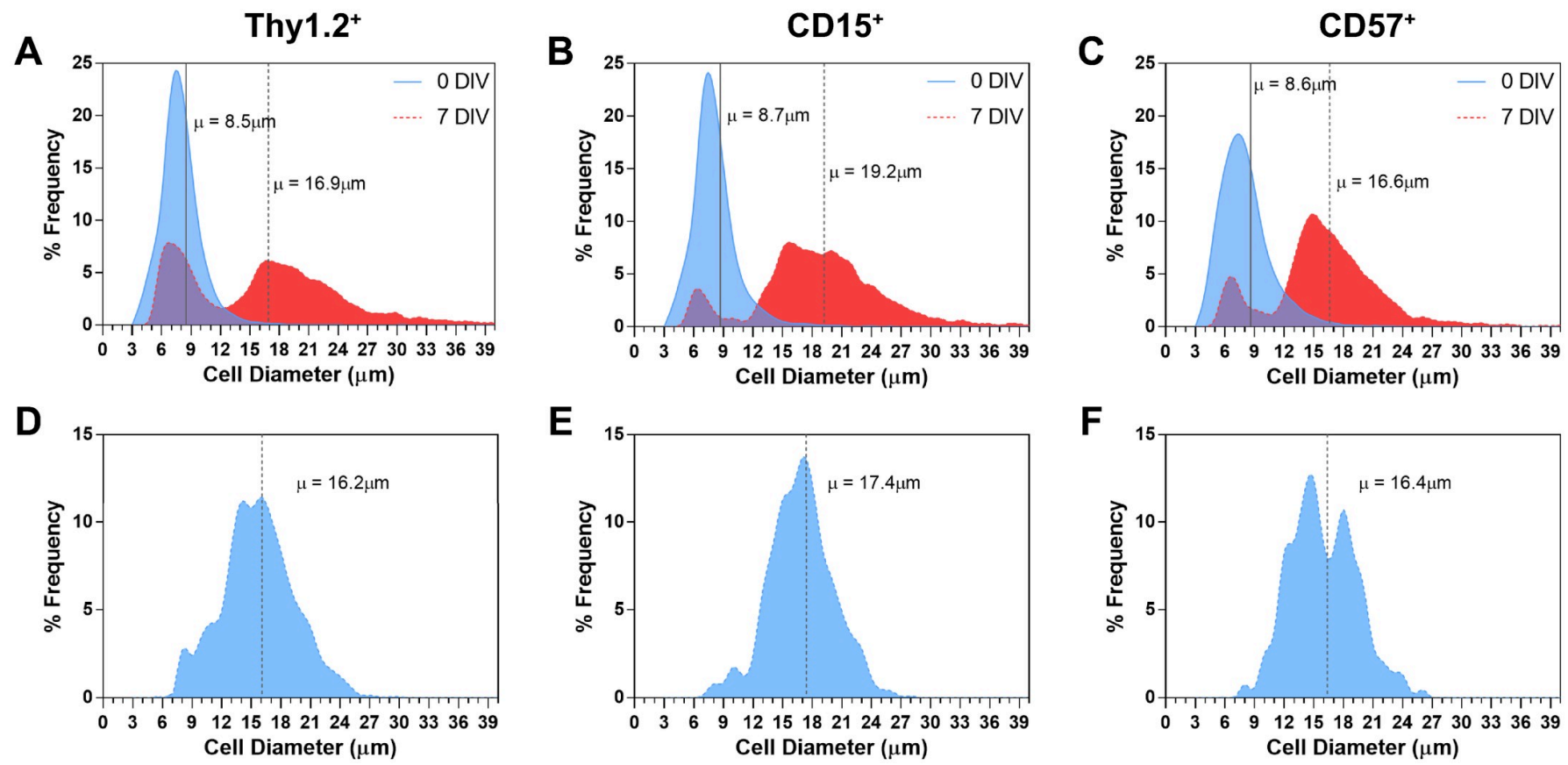

Fig 7. Soma diameter of RGCs and ACs following isolation, culture, and neurite outgrowth. (A,B,C) Distribution frequencies of cell diameter after isolation (0 DIV; shaded blue curve) and 7 DIV (shaded red curve) for all (A), Thy1.2 $2^{+}$, B) CD15 ${ }^{+}$, and (C) $\mathrm{CD} 57^{+}$cells. Vertical solid and dotted lines represent the mean cell diameters at 0 and 7 DIV, respectively. (D,E,F) Cell diameter frequencies of neurite-extending (D), Thy1.2 $2^{+}$, E) CD15 $5^{+}$, and (F) CD57 $7^{+}$cells after 7 DIV, with the vertical dotted lines representing the mean cell diameter for the corresponding cell type. Thy $1.2^{+}: \mathrm{n}=33,692$ (0 DIV), 9,910 (7 DIV), and 2,273 (7 DIV with neurites). CD15 $: \mathrm{n}=21,665$ (0 DIV), 5,798 (7 DIV), and 1,052 (7 DIV with neurites). CD57 $: \mathrm{n}=33,440$ (0 DIV), 6,424 (7 DIV), and 700 (7 DIV with neurites).

https://doi.org/10.1371/journal.pone.0242426.g007

classes of neurons and their neurites are required to determine which RGC and AC subtypes they represent in our culture.

What factors are facilitating neuronal survival and neurite outgrowth in our adult culture systems? Optimization of our culture conditions revealed inverse differences in base media on their effects on cell survival versus the percentage of cells with neurite processes in RGCs and $\mathrm{CD} 15^{+}$neurons. The different base media differ by osmolarity ranking in osmotic concentration as $\mathrm{N}<\mathrm{NA}<\mathrm{DN}=\mathrm{DW}<\mathrm{DNA}[61,62]$. RGCs and $\mathrm{CD} 15^{+}$cells exposed to lower osmolarity $(\mathrm{N})$ increased in cell viability, contrary to adult hippocampal neuronal cultures [63]. Interestingly, increasing osmolarity reduced viability but increased the percentage of cells with neurites in these two cell populations (DNA). Similar increases in neurite extensions occur with PC-12 cell (peripheral neuronal cell line) exposed to hyperosmotic conditions [64]. Vitamin B12, a component found only in N and NA base media, has been shown to protect RGCs from optic nerve transection [65]. As a superoxide scavenger, vitamin B12 may have contributed to the removal of reactive oxygen species that were propagated from the stressors of our isolation method, thus promoting the survival of cultured adult RGCs and $\mathrm{CD} 15^{+}$cells. Lastly, $\mathrm{CO}_{2}$ concentrations may affect different neuronal populations. In our cultures, both RGC and $\mathrm{CD}_{15}{ }^{+}$cells thrived better in $5 \% \mathrm{CO}_{2}$, while $\mathrm{CD} 57^{+}$cell viability improved $(\mathrm{p}=0.07)$ in $10 \%$ $\mathrm{CO}_{2}$, suggesting, $\mathrm{CD} 57^{+}$cells may prefer a more acidic environment. Interestingly, when comparing the two AC populations, unlike for $\mathrm{CD} 15^{+}$cells, culture conditions had little effect on $\mathrm{CD} 57^{+}$cell viability and neurite outgrowth. Taken together, our results suggest that the conditions for cell survival versus neurite outgrowth can differ in the same neuronal population. This is particularly important when considering the treatment of human diseases for which injury is ongoing, such as glaucoma. Similarly, a single culture condition may not be optimal 
for the use of all neuronal types. Therefore, the optimization of culture conditions based on the experimental question is important when studying and screening for neuronal survival, regeneration, phenotype, and physiology.

Cultures of enriched neuronal populations from adults can help us better understand the complexity of the CNS. Adult neuronal cultures can be used as screening tools (Fig 5) and cocultures can be performed to study specific interactions between mature neurons and with other non-neuronal cell types. Additionally, these cultures can be expanded with other experimental methods as a tool to delineate biological relevant questions of neurons that were previously possible only in mitotic somatic cells. The increased versatility and capabilities of adult neuronal cultures complement the various strengths of neuronal cultures using neonatal cells and iPSCs, and will be particularly helpful to further delineate neuronal function in aging and disease in future studies.

\section{Acknowledgments}

We thank Elena Skaribas for critical review of the manuscript.

\section{Author Contributions}

Conceptualization: Yong H. Park, Benjamin J. Frankfort.

Data curation: Yong H. Park, Joshua D. Snook.

Formal analysis: Yong H. Park, Joshua D. Snook, Iris Zhuang.

Funding acquisition: Benjamin J. Frankfort.

Investigation: Yong H. Park, Joshua D. Snook, Iris Zhuang, Guofu Shen.

Methodology: Yong H. Park, Guofu Shen, Benjamin J. Frankfort.

Project administration: Benjamin J. Frankfort.

Supervision: Yong H. Park, Benjamin J. Frankfort.

Writing - original draft: Yong H. Park, Benjamin J. Frankfort.

Writing - review \& editing: Yong H. Park, Iris Zhuang, Benjamin J. Frankfort.

\section{References}

1. Ahlemeyer B, Baumgart-Vogt E. Optimized protocols for the simultaneous preparation of primary neuronal cultures of the neocortex, hippocampus and cerebellum from individual newborn (P0.5) C57BI/6J mice. J Neurosci Methods. 2005; 149(2):110-20. https://doi.org/10.1016/j.jneumeth.2005.05.022 PMID: 16084598.

2. Barres BA, Silverstein BE, Corey DP, Chun LL. Immunological, morphological, and electrophysiological variation among retinal ganglion cells purified by panning. Neuron. 1988; 1(9):791-803. https://doi.org/ 10.1016/0896-6273(88)90127-4 PMID: 2908449.

3. Graber DJ, Harris BT. Purification and culture of spinal motor neurons from rat embryos. Cold Spring Harb Protoc. 2013; 2013(4):319-26. https://doi.org/10.1101/pdb.prot074161 PMID: 23547162.

4. Beaudoin GM 3rd, Lee SH, Singh D, Yuan Y, Ng YG, Reichardt LF, et al. Culturing pyramidal neurons from the early postnatal mouse hippocampus and cortex. Nat Protoc. 2012; 7(9):1741-54. https://doi. org/10.1038/nprot.2012.099 PMID: 22936216.

5. Kumar A, Mallick BN. Long-term primary culture of neurons taken from chick embryo brain: A model to study neural cell biology, synaptogenesis and its dynamic properties. J Neurosci Methods. 2016; 263:123-33. https://doi.org/10.1016/j.jneumeth.2016.02.008 PMID: 26880162.

6. Kobayashi W, Onishi A, Tu HY, Takihara Y, Matsumura M, Tsujimoto K, et al. Culture Systems of Dissociated Mouse and Human Pluripotent Stem Cell-Derived Retinal Ganglion Cells Purified by Two-Step Immunopanning. Invest Ophthalmol Vis Sci. 2018; 59(2):776-87. https://doi.org/10.1167/iovs.1722406 PMID: 29392326. 
7. de Rus Jacquet A. Preparation and Co-Culture of iPSC-Derived Dopaminergic Neurons and Astrocytes. Curr Protoc Cell Biol. 2019; 85(1):e98. https://doi.org/10.1002/cpcb.98 PMID: 31763766.

8. Tukker AM, Wijnolts FMJ, de Groot A, Westerink RHS. Human iPSC-derived neuronal models for in vitro neurotoxicity assessment. Neurotoxicology. 2018; 67:215-25. https://doi.org/10.1016/j.neuro. 2018.06.007 PMID: 29909083.

9. Brewer GJ, Torricelli JR. Isolation and culture of adult neurons and neurospheres. Nat Protoc. 2007; 2 (6):1490-8. https://doi.org/10.1038/nprot.2007.207 PMID: 17545985.

10. Banker GA, Cowan WM. Rat hippocampal neurons in dispersed cell culture. Brain Res. 1977; 126 (3):397-42. https://doi.org/10.1016/0006-8993(77)90594-7 PMID: 861729.

11. Bott CJ, Johnson CG, Yap CC, Dwyer ND, Litwa KA, Winckler B. Nestin in immature embryonic neurons affects axon growth cone morphology and Semaphorin3a sensitivity. Mol Biol Cell. 2019; 30 (10):1214-29. https://doi.org/10.1091/mbc.E18-06-0361 PMID: 30840538.

12. Kunzevitzky NJ, Almeida MV, Goldberg JL. Amacrine cell gene expression and survival signaling: differences from neighboring retinal ganglion cells. Invest Ophthalmol Vis Sci. 2010; 51(7):3800-12. https:// doi.org/10.1167/iovs.09-4540 PMID: 20445109.

13. Edwards D, Sommerhage F, Berry B, Nummer H, Raquet M, Clymer B, et al. Comparison of NMDA and AMPA Channel Expression and Function between Embryonic and Adult Neurons Utilizing Microelectrode Array Systems. ACS Biomater Sci Eng. 2017; 3(12):3525-33. https://doi.org/10.1021/ acsbiomaterials.7b00596 PMID: 29250595.

14. Prilutsky D, Palmer NP, Smedemark-Margulies N, Schlaeger TM, Margulies DM, Kohane IS. iPSCderived neurons as a higher-throughput readout for autism: promises and pitfalls. Trends Mol Med. 2014; 20(2):91-104. https://doi.org/10.1016/j.molmed.2013.11.004 PMID: 24374161.

15. Handel AE, Chintawar S, Lalic T, Whiteley E, Vowles J, Giustacchini A, et al. Assessing similarity to primary tissue and cortical layer identity in induced pluripotent stem cell-derived cortical neurons through single-cell transcriptomics. Hum Mol Genet. 2016; 25(5):989-1000. PMID: 26740550.

16. London $A$, Benhar I, Schwartz $M$. The retina as a window to the brain-from eye research to CNS disorders. Nat Rev Neurol. 2013; 9(1):44-53. https://doi.org/10.1038/nrneurol.2012.227 PMID: 23165340

17. Trimarchi JM, Stadler MB, Roska B, Billings N, Sun B, Bartch B, et al. Molecular heterogeneity of developing retinal ganglion and amacrine cells revealed through single cell gene expression profiling. $\mathrm{J}$ Comp Neurol. 2007; 502(6):1047-65. https://doi.org/10.1002/cne.21368 PMID: 17444492.

18. Zalis MC, Johansson S, Englund-Johansson U. Immunocytochemical Profiling of Cultured Mouse Primary Retinal Cells. J Histochem Cytochem. 2017; 65(4):223-39. https://doi.org/10.1369/ 0022155416689675 PMID: 28151698.

19. Rodriguez AR, de Sevilla Muller LP, Brecha NC. The RNA binding protein RBPMS is a selective marker of ganglion cells in the mammalian retina. J Comp Neurol. 2014; 522(6):1411-43. https://doi.org/10. 1002/cne.23521 PMID: 24318667.

20. Macosko EZ, Basu A, Satija R, Nemesh J, Shekhar K, Goldman M, et al. Highly Parallel Genome-wide Expression Profiling of Individual Cells Using Nanoliter Droplets. Cell. 2015; 161(5):1202-14. https:// doi.org/10.1016/j.cell.2015.05.002 PMID: 26000488.

21. Rheaume BA, Jereen A, Bolisetty M, Sajid MS, Yang Y, Renna K, et al. Single cell transcriptome profiling of retinal ganglion cells identifies cellular subtypes. Nat Commun. 2018; 9(1):2759. https://doi.org/ 10.1038/s41467-018-05134-3 PMID: 30018341.

22. Shekhar K, Lapan SW, Whitney IE, Tran NM, Macosko EZ, Kowalczyk M, et al. Comprehensive Classification of Retinal Bipolar Neurons by Single-Cell Transcriptomics. Cell. 2016; 166(5):1308-23 e30. https://doi.org/10.1016/j.cell.2016.07.054 PMID: 27565351.

23. Abd-El-Barr MM, Pennesi ME, Saszik SM, Barrow AJ, Lem J, Bramblett DE, et al. Genetic dissection of rod and cone pathways in the dark-adapted mouse retina. J Neurophysiol. 2009; 102(3):1945-55. https://doi.org/10.1152/jn.00142.2009 PMID: 19587322.

24. Menon M, Mohammadi S, Davila-Velderrain J, Goods BA, Cadwell TD, Xing Y, et al. Single-cell transcriptomic atlas of the human retina identifies cell types associated with age-related macular degeneration. Nat Commun. 2019; 10(1):4902. https://doi.org/10.1038/s41467-019-12780-8 PMID: 31653841.

25. Yan W, Laboulaye MA, Tran NM, Whitney IE, Benhar I, Sanes JR. Mouse Retinal Cell Atlas: Molecular Identification of over Sixty Amacrine Cell Types. J Neurosci. 2020; 40(27):5177-95. https://doi.org/10. 1523/JNEUROSCI.0471-20.2020 PMID: 32457074.

26. Sridhar A, Hoshino A, Finkbeiner CR, Chitsazan A, Dai L, Haugan AK, et al. Single-Cell Transcriptomic Comparison of Human Fetal Retina, hPSC-Derived Retinal Organoids, and Long-Term Retinal Cultures. Cell Rep. 2020; 30(5):1644-59 e4. https://doi.org/10.1016/j.celrep.2020.01.007 PMID: 32023475 . 
27. Lukowski SW, Lo CY, Sharov AA, Nguyen Q, Fang L, Hung SS, et al. A single-cell transcriptome atlas of the adult human retina. EMBO J. 2019; 38(18):e100811. https://doi.org/10.15252/embj.2018100811 PMID: 31436334.

28. Sanes JR, Masland RH. The types of retinal ganglion cells: current status and implications for neuronal classification. Annu Rev Neurosci. 2015; 38:221-46. https://doi.org/10.1146/annurev-neuro-071714034120 PMID: 25897874.

29. Jeon CJ, Strettoi E, Masland RH. The major cell populations of the mouse retina. J Neurosci. 1998; 18 (21):8936-46. https://doi.org/10.1523/JNEUROSCI.18-21-08936.1998 PMID: 9786999.

30. Brown RL, Xiong WH, Peters JH, Tekmen-Clark M, Strycharska-Orczyk I, Reed BT, et al. TRPM3 expression in mouse retina. PLoS One. 2015; 10(2):e0117615. https://doi.org/10.1371/journal.pone. 0117615 PMID: 25679224.

31. Torero Ibad R, Rheey J, Mrejen S, Forster V, Picaud S, Prochiantz A, et al. Otx2 promotes the survival of damaged adult retinal ganglion cells and protects against excitotoxic loss of visual acuity in vivo. $J$ Neurosci. 2011; 31(14):5495-503. https://doi.org/10.1523/JNEUROSCI.0187-11.2011 PMID: 21471386.

32. $\mathrm{Ma} \mathrm{CH}$, Taylor JS. Trophic responsiveness of purified postnatal and adult rat retinal ganglion cells. Cell Tissue Res. 2010; 339(2):297-310. https://doi.org/10.1007/s00441-009-0897-4 PMID: 19936794.

33. Wehrwein E, Thompson SA, Coulibaly SF, Linn DM, Linn CL. Acetylcholine protection of adult pig retinal ganglion cells from glutamate-induced excitotoxicity. Invest Ophthalmol Vis Sci. 2004; 45(5):153143. https://doi.org/10.1167/iovs.03-0406 PMID: 15111612.

34. Iwamoto K, Mata D, Linn DM, Linn CL. Neuroprotection of rat retinal ganglion cells mediated through alpha7 nicotinic acetylcholine receptors. Neuroscience. 2013; 237:184-98. https://doi.org/10.1016/j. neuroscience.2013.02.003 PMID: 23402849.

35. Hartwick AT, Hamilton CM, Baldridge WH. Glutamatergic calcium dynamics and deregulation of rat retinal ganglion cells. J Physiol. 2008; 586(14):3425-46. https://doi.org/10.1113/jphysiol.2008.154609 PMID: 18483069.

36. Park YH, Snook JD, Ostrin EJ, Kim S, Chen R, Frankfort BJ. Transcriptomic profiles of retinal ganglion cells are defined by the magnitude of intraocular pressure elevation in adult mice. Sci Rep. 2019; 9 (1):2594. https://doi.org/10.1038/s41598-019-39141-1 PMID: 30796289.

37. Winzeler A, Wang JT. Purification and culture of retinal ganglion cells from rodents. Cold Spring Harb Protoc. 2013; 2013(7):643-52. https://doi.org/10.1101/pdb.prot074906 PMID: 23818667.

38. Schwieger J, Esser KH, Lenarz T, Scheper V. Establishment of a long-term spiral ganglion neuron culture with reduced glial cell number: Effects of AraC on cell composition and neurons. J Neurosci Methods. 2016; 268:106-16. https://doi.org/10.1016/j.jneumeth.2016.05.001 PMID: 27154027.

39. Genaro-Mattos TC, Anderson A, Allen LB, Korade Z, Mirnics K. Cholesterol Biosynthesis and Uptake in Developing Neurons. ACS Chem Neurosci. 2019; 10(8):3671-81. https://doi.org/10.1021/ acschemneuro.9b00248 PMID: 31244054.

40. Allen LB, Genaro-Mattos TC, Porter NA, Mirnics K, Korade Z. Desmosterolosis and desmosterol homeostasis in the developing mouse brain. J Inherit Metab Dis. 2019; 42(5):934-43. https://doi.org/10 1002/jimd.12088 PMID: 30891795.

41. Blanks JC, Johnson LV. Specific binding of peanut lectin to a class of retinal photoreceptor cells. A species comparison. Invest Ophthalmol Vis Sci. 1984; 25(5):546-57. PMID: 6715128.

42. Koso H, Minami C, Tabata $Y$, Inoue M, Sasaki E, Satoh S, et al. CD73, a novel cell surface antigen that characterizes retinal photoreceptor precursor cells. Invest Ophthalmol Vis Sci. 2009; 50(11):5411-8. https://doi.org/10.1167/iovs.08-3246 PMID: 19515998.

43. Jakobs TC, Ben Y, Masland RH. CD15 immunoreactive amacrine cells in the mouse retina. J Comp Neurol. 2003; 465(3):361-71. https://doi.org/10.1002/cne.10845 PMID: 12966561.

44. Huettner JE, Baughman RW. Primary culture of identified neurons from the visual cortex of postnatal rats. J Neurosci. 1986; 6(10):3044-60. https://doi.org/10.1523/JNEUROSCI.06-10-03044.1986 PMID: 3760948.

45. Barres BA. Designing and troubleshooting immunopanning protocols for purifying neural cells. Cold Spring Harb Protoc. 2014; 2014(12):1342-7. https://doi.org/10.1101/pdb.ip073999 PMID: 25447277.

46. Xu H, lyer N, Huettner JE, Sakiyama-Elbert SE. A puromycin selectable cell line for the enrichment of mouse embryonic stem cell-derived V3 interneurons. Stem Cell Res Ther. 2015; 6:220. https://doi.org/ 10.1186/s13287-015-0213-z PMID: 26555777.

47. Tian R, Gachechiladze MA, Ludwig CH, Laurie MT, Hong JY, Nathaniel D, et al. CRISPR InterferenceBased Platform for Multimodal Genetic Screens in Human iPSC-Derived Neurons. Neuron. 2019; 104 (2):239-55 e12. https://doi.org/10.1016/j.neuron.2019.07.014 PMID: 31422865. 
48. Zhong ZH, Jiang WQ, Cesare AJ, Neumann AA, Wadhwa R, Reddel RR. Disruption of telomere maintenance by depletion of the MRE11/RAD50/NBS1 complex in cells that use alternative lengthening of telomeres. J Biol Chem. 2007; 282(40):29314-22. https://doi.org/10.1074/jbc.M701413200 PMID: 17693401.

49. Sun W, Li N, He S. Large-scale morphological survey of mouse retinal ganglion cells. J Comp Neurol. 2002; 451(2):115-26. https://doi.org/10.1002/cne.10323 PMID: 12209831.

50. Baden T, Berens $\mathrm{P}$, Franke $\mathrm{K}$, Roman Roson M, Bethge M, Euler T. The functional diversity of retinal ganglion cells in the mouse. Nature. 2016; 529(7586):345-50. https://doi.org/10.1038/nature16468 PMID: 26735013.

51. Zhu Y, Xu J, Hauswirth WW, DeVries SH. Genetically targeted binary labeling of retinal neurons. J Neurosci. 2014; 34(23):7845-61. https://doi.org/10.1523/JNEUROSCI.2960-13.2014 PMID: 24899708.

52. Newkirk GS, Hoon M, Wong RO, Detwiler PB. Response Properties of a Newly Identified Tristratified Narrow Field Amacrine Cell in the Mouse Retina. PLoS One. 2015; 10(9):e0137702. https://doi.org/10. 1371/journal.pone.0137702 PMID: 26352594.

53. Frade JM, Ovejero-Benito MC. Neuronal cell cycle: the neuron itself and its circumstances. Cell Cycle. 2015; 14(5):712-20. https://doi.org/10.1080/15384101.2015.1004937 PMID: 25590687.

54. Eide L, McMurray CT. Culture of adult mouse neurons. Biotechniques. 2005; 38(1):99-104. https://doi. org/10.2144/05381RR02 PMID: 15679091.

55. Fileta JB, Huang W, Kwon GP, Filippopoulos T, Ben Y, Dobberfuhl A, et al. Efficient estimation of retinal ganglion cell number: a stereological approach. J Neurosci Methods. 2008; 170(1):1-8. https://doi.org/ 10.1016/j.jneumeth.2007.12.008 PMID: 18241929.

56. Keller JM, Frega M. Past, Present, and Future of Neuronal Models In Vitro. Adv Neurobiol. 2019; 22:317. https://doi.org/10.1007/978-3-030-11135-9_1 PMID: 31073930.

57. Berry BJ, Smith AST, Young JE, Mack DL. Advances and Current Challenges Associated with the Use of Human Induced Pluripotent Stem Cells in Modeling Neurodegenerative Disease. Cells Tissues Organs. 2018; 205(5-6):331-49. https://doi.org/10.1159/000493018 PMID: 30300891.

58. Duan X, Qiao M, Bei F, Kim IJ, He Z, Sanes JR. Subtype-specific regeneration of retinal ganglion cells following axotomy: effects of osteopontin and mTOR signaling. Neuron. 2015; 85(6):1244-56. https:// doi.org/10.1016/j.neuron.2015.02.017 PMID: 25754821.

59. Tran NM, Shekhar K, Whitney IE, Jacobi A, Benhar I, Hong G, et al. Single-Cell Profiles of Retinal Ganglion Cells Differing in Resilience to Injury Reveal Neuroprotective Genes. Neuron. 2019; 104(6):103955 e12. https://doi.org/10.1016/j.neuron.2019.11.006 PMID: 31784286.

60. Kunzevitzky NJ, Willeford KT, Feuer WJ, Almeida MV, Goldberg JL. Amacrine cell subtypes differ in their intrinsic neurite growth capacity. Invest Ophthalmol Vis Sci. 2013; 54(12):7603-13. https://doi.org/ 10.1167/iovs.13-12691 PMID: 24130183.

61. Sharma S, Chakravarthy H, Suresh G, Devanathan V. Adult Goat Retinal Neuronal Culture: Applications in Modeling Hyperglycemia. Front Neurosci. 2019; 13:983. https://doi.org/10.3389/fnins.2019. 00983 PMID: 31607843

62. Kleinsimlinghaus K, Marx R, Serdar M, Bendix I, Dietzel ID. Strategies for repair of white matter: influence of osmolarity and microglia on proliferation and apoptosis of oligodendrocyte precursor cells in different basal culture media. Front Cell Neurosci. 2013; 7:277. https://doi.org/10.3389/fncel.2013.00277 PMID: 24421756

63. Brewer GJ. Isolation and culture of adult rat hippocampal neurons. J Neurosci Methods. 1997; 71 (2):143-55. https://doi.org/10.1016/s0165-0270(96)00136-7 PMID: 9128149.

64. Kano Y, Nohno T, Takahashi R, Hasegawa T, Hiragami F, Kawamura K, et al. cAMP and calcium ionophore induce outgrowth of neuronal processes in PC12 mutant cells in which nerve growth factorinduced outgrowth of neuronal processes is impaired. Neurosci Lett. 2001; 303(1):21-4. https://doi.org/ 10.1016/s0304-3940(01)01676-7 PMID: 11297814.

65. Chan W, Almasieh M, Catrinescu MM, Levin LA. Cobalamin-Associated Superoxide Scavenging in Neuronal Cells Is a Potential Mechanism for Vitamin B12-Deprivation Optic Neuropathy. Am J Pathol. 2018; 188(1):160-72. https://doi.org/10.1016/j.ajpath.2017.08.032 PMID: 29037851. 